\title{
Estimation of Capacity of Urban Roads under Heterogeneous Traffic Conditions
}

\author{
${ }^{* 1}$ Ankush Asati, ${ }^{2}$ Udaysingh Patil, ${ }^{3}$ Vivek P. Joshi \\ 1,2,3 Shri Ramdeobaba College of Engineering and Management, Nagpur \\ Email: ankush2508@gmail.com,patil.udaysingh4@gmail.com,Vivekj219@gmail.com
}

Received: 06th November 2019, Accepted: 10th February 2020, Published: 29th February 2020

\begin{abstract}
Now-a-days, the traffic condition in India is of heterogeneous nature due to its dynamic nature. As the traffic on roads rises rapidly therefore, it is very essential to determine, prepare and design the roadway features according to the future .The objective of this paper is to estimate capacity for heterogeneous traffic condition. Estimation of traffic volume on road is relatively tough. Value of PCU can be used to measure the flow of traffic. Urban road of Nagpur i.e. from Hingna T-point to Chatrapati Square is selected to calculate its capacity. This study emphasizes the need for capacity estimation to plan, design and control the rising vehicular population. The types of roads and the agencies controlling it were characterized. The Inner Ring Road from Hingna T-point to Chatrapati Square was divided into seven zones for the ease of study. Afterwards, the Traffic Volume study was conducted by direct method of counting using tally sheets which is also called Paper and Pen method. The data collected was used for calculation of PCU value. Then, using Selected Maxima method capacity of the stretch was calculated and the effect of width on the capacity was studied and measures were suggested to improve the capacity.
\end{abstract}

\section{Keywords}

Capacity, Direct Method, PCU, Traffic

\section{Introduction}

Due to rapid growth of population in India, [1][7] the traffic conditions are becoming heterogeneous in nature owing to various static and dynamic features resulted may be due to vehicle conditions, types of vehicles, different lanes, behavior of driver etc. The volume of traffic is increasing day by day and this increased volume sometimes overdoes the normal limit. Therefore, for improvement in vehicular road traffic, study of highway traffic [2][9] plays an important role in preparing, designing and planning roadway facilities. Present study is intended to analyze capacity for urban roads in heterogeneous condition.

\section{Preliminary Survey}

The data for this study were collected at more than 3 sections of two-lane road to determine the lane width, shoulder condition and pavement roughness on capacity of two lane roads. The details of these sections are given in Tables-1 to 4.

\begin{tabular}{|l|c|}
\hline Description & Width(m) \\
\hline Single lane without kerbs & 4.5 \\
\hline Double lane without kerbs & 9 \\
\hline Double lane with kerbs & 9.5 \\
\hline
\end{tabular}

Table 1: Carriageway Width

\begin{tabular}{|l|c|c|}
\hline & Without sidewalk(m) & With sidewalk (m) \\
\hline Left Shoulder width & 4 & 6 \\
\hline Right Shoulder width & 4 & 6 \\
\hline
\end{tabular}

Table 2: Shoulder Width

\begin{tabular}{|l|l|}
\hline Location & \multicolumn{1}{c|}{ Lane width } \\
\hline Tpoint-Mangalmurti & 9.1 \\
\hline Mangalmurti-Trimurti & 9 \\
\hline Trimurti-Sambhaji & 9.3 \\
\hline Sambhaji-Padole & 9.5 \\
\hline Padole-Pratap nagar & 9.2 \\
\hline Pratap nagar-Orange city & 9.3 \\
\hline Orange city-Chatrapati & 9.6 \\
\hline
\end{tabular}

Table 3: Lane Width 


\begin{tabular}{|l|c|c|c|}
\hline Vehicle categories & Length in $\mathbf{~ m}$ & Breadth in $\mathbf{~ m}$ & Total areas in m2 \\
\hline Car & 3.5 & 1.5 & 5.5 \\
\hline 2-Wheeler & 1.8 & 0.6 & 1.2 \\
\hline 3-wheeler & 3.2 & 1.4 & 4.4 \\
\hline Bicycle & 1.9 & 0.45 & 0.85 \\
\hline Bus & 11.4 & 2.5 & 28.5 \\
\hline Heavy vehicle & 13.6 & 2.42 & 32.91 \\
\hline
\end{tabular}

\section{Table 4: Standard Physical Vehicle Dimension of All Vehicles}

\section{Methodology}

Traffic volume is counted using [10] manual method, groups were divided for various selected locations and vehicle passing the roads were recorded using tally marks. Use of automatic methods was prohibited due to lack of infrastructure, necessary authorization etc. Area Considered is: Chatrapati Sq to Hingna T-Point (kms) [Nagpur]

\section{Data Collection}

\begin{tabular}{|l|c|c|c|c|l|c|c|c|c|}
\hline \multicolumn{5}{|c|}{ Location : Hingna-T-point to Mangalmurti } & \multicolumn{4}{c|}{ Location :MangalmurtiSq to Hingna T-Point } \\
\hline & 11 -Aug & 04-Feb & 08-Jun & Total & & 11 -Aug & 04-Feb & 08-Jun & Total \\
\hline Bicycle & 39 & 25 & 59 & 122 & Bicycle & 72 & 51 & 41 & 282 \\
\hline 2-Wheeler & 2876 & 2477 & 3642 & 8995 & 2-Wheeler & 3152 & 2738 & 3432 & 9322 \\
\hline 3-Wheeler & 148 & 130 & 166 & 444 & 3-Wheeler & 178 & 142 & 157 & 477 \\
\hline Car & 857 & 938 & 1452 & 3247 & Car & 1145 & 1201 & 1232 & 3578 \\
\hline Bus & 78 & 54 & 63 & 195 & Bus & 93 & 71 & 63 & 167 \\
\hline Truck & 42 & 37 & 28 & 107 & Truck & 43 & 31 & 38 & 112 \\
\hline
\end{tabular}

Table 5: Collection of Data from Various Location

\section{Passenger Car Unit [PCU]}

\begin{tabular}{|l|c|c|c|}
\hline Vehicle Categories & Length $\mathrm{m}$ & Breadth $\mathrm{m}$ & Total area $\mathrm{m}$ \\
\hline Bicycle & 1.9 & 0.45 & 0.85 \\
\hline 2- Wheelers & 1.8 & 0.6 & 1.2 \\
\hline 3- Wheelers & 3.2 & 1.4 & 4.4 \\
\hline Car & 3.5 & 1.5 & 5.5 \\
\hline Bus & 11.4 & 2.5 & 28.5 \\
\hline Truck & 13.6 & 2.42 & 32.91 \\
\hline
\end{tabular}

Table 6: Physical Vehicle Dimension of All Vehicles

\begin{tabular}{|l|l|l|l|}
\hline \multirow{2}{*}{ Vehicle categories } & Speed parameters $(\mathrm{km} / \mathrm{hr})$ & \multicolumn{2}{|l|}{} \\
\cline { 2 - 4 } & Highest speed & Lowest speed & Medium speed \\
\hline Bus & 76.44 & 26 & 51.07 \\
\hline Truck & 71 & 20.6 & 46.12 \\
\hline Car & 101.85 & 35 & 68.21 \\
\hline 2- wheeler & 82.04 & 25.34 & 54.2 \\
\hline 3- wheeler & 48.08 & 20.6 & 34.35 \\
\hline Bicycle & 29.85 & 13.5 & 21.3 \\
\hline
\end{tabular}

Table 7: Speed Parameters

\begin{tabular}{|l|c|}
\hline Vehicle & PCU \\
\hline Bicycle & 0.61 \\
\hline 2-Wheelers & 0.28 \\
\hline 3- Wheelers & 1.52 \\
\hline Car & 1 \\
\hline Bus & 6.58 \\
\hline Truck & 7.86 \\
\hline
\end{tabular}

Table 8: Calculated PCU 


\section{Capacity Estimation}

To determine capacity values many methods are available. [6] There are two modes direct and indirect methods; the capacity of road can be estimated by using density of traffic, speed, width of roadway, headway etc.

Selected Maxima Method is adopted in this study. [4]The traffic volume data was further analyzed to estimate the capacity. The maximum flow interval was then identified.Then data was recorded for 5 min interval .This obtained value was multiplied by 12 for estimating capacity flow per hour. [3] The capacity was normalized as the width of carriage way was varying i.e for a width of $7 \mathrm{~m}-2$ lane road using following equation:

$\mathrm{NC}=\mathrm{TC} * \mathrm{SW} / \mathrm{CW}$

Where,

NC-Normalized Capacity

TC-Total Capacity

CW-Carriageway width of section at site

SW-Standard Width of $7 \mathrm{~m}$

In this study, Predefined location in Nagpur was selected and traffic volume at various sections was recorded for two way roads. Estimation of PCU of various classes of vehicles for mixed traffic condition on specified location is presented. From fig. 1 it can be observed that the value of PCU increases with width of carriageway and capacity of two lane road also increases with increase in total width of carriageway.

\begin{tabular}{|c|c|c|c|c|}
\hline Location & $\begin{array}{c}\text { Peak hour } \\
\text { volume }\end{array}$ & $\begin{array}{c}\text { Max flow in 5 } \\
\text { min }\end{array}$ & $\begin{array}{c}\text { Total } \\
\text { capacity }\end{array}$ & $\begin{array}{c}\text { Normalized } \\
\text { capacity }\end{array}$ \\
\hline TrimurtiSq -MangalmurtiSq & 2046 & 249 & 2988 & 2179 \\
\hline MangalmurtiSq -TrimurtiSq & 1831 & 215 & 2580 & 1881 \\
\hline Mangalmurti -Hingna T-Point & 1992 & 219 & 2628 & 1958 \\
\hline Hingna T-Point - Mangalmurti & 1873 & 226 & 2712 & 2019 \\
\hline ChatrapatiSq- Orange City Sq & 2054 & 216 & 2592 & 1890 \\
\hline Orange CitySq- ChatrapatiSq & 1869 & 220 & 2640 & 1925 \\
\hline PadoleSq - PratapNagar Sq & 1801 & 199 & 2388 & 1816 \\
\hline PratapNagarSq - Padole Sq & 1840 & 214 & 2568 & 1954 \\
\hline PratapNagar - Orange City Sq & 1719 & 190 & 2280 & 1734 \\
\hline Orange City- PratapNagarSq & 1924 & 226 & 2712 & 2063 \\
\hline TrimurtiSq - Sambhaji Sq & 1900 & 205 & 2460 & 1851 \\
\hline SambhajiSq- TrimurtiSq & 1899 & 228 & 2736 & 2059 \\
\hline SambhajiSq- PadoleSq & 1852 & 211 & 2532 & 1926 \\
\hline PadoleSq - Sambhaji Sq & 1807 & 201 & 2412 & 1835 \\
\hline
\end{tabular}

Table 9: Estimated Capacities by Volume Method

\begin{tabular}{|c|c|c|c|}
\hline Location & Carriageway width & Obtained capacity & $\begin{array}{c}\text { Total } \\
\text { Capacity }\end{array}$ \\
\hline TrimurtiSq-MangalmurtiSq & \multirow{2}{*}{9.6} & 2988 & \multirow{2}{*}{5568} \\
\hline MangalmurtiSq-TrimurtiSq & & 2580 & \\
\hline MangalmurtiSq -Hingna T-Point & \multirow{2}{*}{9.4} & 2628 & \multirow{2}{*}{5340} \\
\hline Hingna T-point - Mangalmurti Sq & & 2712 & \\
\hline ChatrapatiSq-Orange City Sq & \multirow{2}{*}{9.6} & 2592 & \multirow{2}{*}{5232} \\
\hline Orange City- SqChatrapatiSq & & 2640 & \\
\hline PadoleSq- PratapNagarSq & \multirow{2}{*}{9.2} & 2388 & \multirow{2}{*}{4956} \\
\hline PratapNagarSq - Padole Sq & & 2568 & \\
\hline PratapNagarSq - Orange City Sq & \multirow{2}{*}{9.2} & 2280 & \multirow{2}{*}{4992} \\
\hline Orange City Sq- PratapNagarSq & & 2712 & \\
\hline TrimurtiSq-SambhajiSq & \multirow{2}{*}{9.3} & 2460 & \multirow{2}{*}{5196} \\
\hline SambhajiSq - Trimurti Sq & & 2736 & \\
\hline SambhajiSq - Padole Sq & \multirow{2}{*}{9.2} & 2532 & \multirow{2}{*}{4944} \\
\hline PadoleSq - Sambhaji Sq & & 2412 & \\
\hline
\end{tabular}

Table 10: Effect of Lane Width on Capacity 


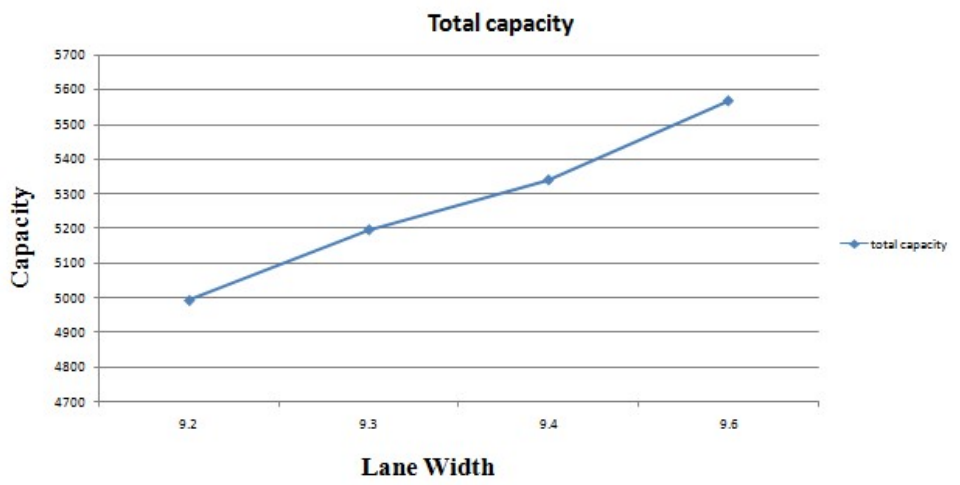

Fig. 1: Graph of Capacity vs Lane Width

\section{Measures for Improving the Capacity of Urban Roads}

After exhaustive study, following measures were suggested to enhance capacity of specified location and may be incorporated in other similar locations.

1. Prohibition of street parking of vehicles with subsequent development of off-street parking facilities.

2. Segregation of the bi-directional traffic flow through central median.

3. Provision for slow moving vehicles such as animal drawn carts, rickshaws, tangas etc. i.e segregation of right of way.

4. Imposing restrictions on the movement of animal drawn /other slow moving vehicles, and /or heavy commercial vehicles on busy arterial/ sub-arterials during selected periods, specially the peak hours.

5. Reduction of roadside friction through control of abutting land-use and roadside commercial activity.

6. Banning certain conflicting movements at major intersections, particularly during peak hours.

7. Controlling cross traffic and side traffic by regulating the gap in medians.

8. Improving traffic discipline road markings, education and publicity.

\section{Conclusion}

Capacity of road varies with location, composition, time, vehicle, driver and many other factors. It can be concluded that direct empirical methods would be appropriate for the calculation of capacity as there is variation in dimensions of roads, lack of discipline w.r.t driving in lanes etc. The capacity observed was 5568 PCU by selected maxima method for 5 min intervals. This increase in capacity was seen due to extreme changes in the flow of traffic and behaviour of drivers on roads leading to more aggressive nature of driver. It is also observed that due to increase volume, the gaps between the vehicles are reduced now which is less than the recommended values and vehicles are traversing with abridged headway \& side clearance. PCE values given in IRC for autorickshaws and for motorized 2 wheelers appears to be on higher side compared to actual scenario i.e 2 and 0.75 (for more than $10 \%$ of the total traffic) respectively. Further more research is required for estimation of PCU as there are no acceptable values for specified conditions.

\section{References}

1. Arpan Mehar, (2013) decide the limit of Indian thruway in assorted rush hour gridlock stream working circumstances by the utilization of microscopic simulation programming (VISSIM).

2. Bang, K.L., Carlsson, A. and Palgunadi (1995), "Development of Speed Flow Relationship for Indonesia Rural Roads Using Empirical Data and Simulation”, Transportation Research Record 1484, Transportation Research Board, Washington D.C., pp. 24-32.

3. Chandra, S. and Goyal, N. K., (2001), "Effect of Grade on Capacity of Two- Lane Road", HB No. 64, IRC, New Delhi, pp. 77.

4. Chandra et.al, (2003) contemplated impact on the limit by methods for path width of streets in shifted movement conditions.

5. Chetan R. Patel and G.J Joshi(2014) considered "Blended movement speed-stream conduct under impact of street side grinding and non-mechanized vehicles.

6. Fi, I. (1994), "Highway Capacity and Level of Service in Highway: Experience with Intersection without Traffic Signals", Country Reports of Second International Symposium

7. Prakash, V. (1970), “Highway Shoulder”, Journal of Indian Roads Congress, Vol. 33-3, pp. 441-446. 
8. Pratik Mankar (2016) gives look into work in the territory of blended activity stream condition. Creator contemplated impact on limit by methods for path width of roadsin fluctuated activity conditions.

9. Taragin, A and Eckhardt. H.G. (1953), "Effect of Shoulders on Speed and Lateral Placement of Motor Vehicles", HB Proceedings, Vol. 32, pp. 371-82.

10. Yagar, S. and Aerde, M.V. (1983), "Geometric and Environmental Effects on Speeds of 2-Lane Highways", Transportation Research-A, Vol. 17A, No. 4, pp. 315-325. 